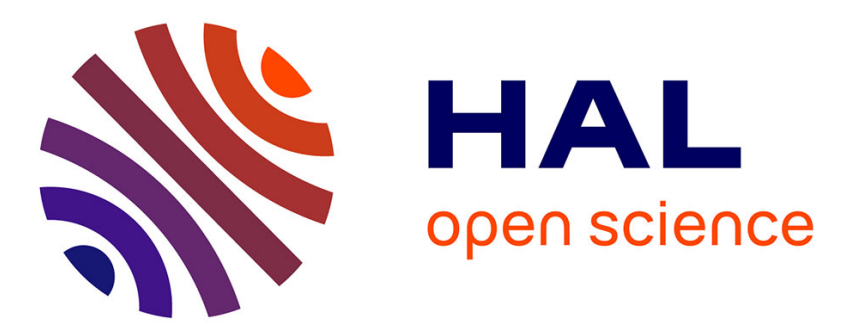

\title{
Fraser syndrome: review of the literature illustrated by a historical adult case
}

\author{
Jebrane Bouaoud, Matthieu Olivetto, Sylvie Testelin, Stéphanie Dakpé, \\ Jérémie Bettoni, Bernard Devauchelle
}

\section{- To cite this version:}

Jebrane Bouaoud, Matthieu Olivetto, Sylvie Testelin, Stéphanie Dakpé, Jérémie Bettoni, et al.. Fraser syndrome: review of the literature illustrated by a historical adult case. International Journal of Oral and Maxillofacial Surgery, 2020, 49 (10), pp.1245-1253. 10.1016/j.ijom.2020.01.007 . hal-03047958

\section{HAL Id: hal-03047958 \\ https: / hal.sorbonne-universite.fr/hal-03047958}

Submitted on 9 Dec 2020

HAL is a multi-disciplinary open access archive for the deposit and dissemination of scientific research documents, whether they are published or not. The documents may come from teaching and research institutions in France or abroad, or from public or private research centers.
L'archive ouverte pluridisciplinaire HAL, est destinée au dépôt et à la diffusion de documents scientifiques de niveau recherche, publiés ou non, émanant des établissements d'enseignement et de recherche français ou étrangers, des laboratoires publics ou privés. 


\section{TITLE PAGE}

Fraser syndrome: review of literature illustrated by an historical adult case

\section{Author names and affiliations:}

Jebrane Bouaoud ${ }^{\mathrm{a}, \mathrm{b}}$, Matthieu Olivetto ${ }^{a}$, Sylvie Testelin ${ }^{a}$, Stephanie Dakpe ${ }^{a}$, Jeremie Bettoni ${ }^{\mathrm{a}}$, Bernard Devauchelle ${ }^{a}$

a. Department of Maxillofacial Surgery, University Hospital of Amiens, Avenue Laennec 80000, Amiens Cedex 1, France.

b. Department of Maxillo-facial Surgery and Stomatology, Pitié-Salpétrière Hospital, Pierre et Marie Curie University Paris 6, Sorbonne Paris Cite University, AP-HP, Paris, 75013, France

Corresponding author:

Jebrane Bouaoud, M.D

Department of Maxillo-facial Surgery and Stomatology, Pitié-Salpétrière Hospital, Pierre et Marie Curie University Paris 6, Sorbonne Paris Cite University, AP-HP, Paris, 75013, France

E-mail_jebrane.bouaoud@gmail.com

Phone\# $\quad+33142161049$

Keywords: Fraser syndrome; cryptophthalmos, syndactyly; Rare conditions Genetic, autosomal recessive 


\section{Abstract}

2 Fraser syndrome (cryptophthalmos-syndactyly syndrome) is a rare autosomal recessive malformation

3 disorder. The first description of the syndrome was reported by George Fraser in 1962. The

4 diagnostic is based on major criteria and minor criteria established by van Haelst et al., In 2007.

5 Unilateral or bilateral cryptophthalmos, syndactyly, unilateral renal agenesis and genital anomalies

6 are the most frequent anomalies. Several maxillofacial, oro-dental, ear-nose-throat, hormonal and

7 anorectal disorders are reported. Cardiac malformations, and musculoskeletal anomalies are

8 uncommon. The syndrome id related to mutations in three different genes (FRAS1, FREM2, and

9 GRIP1) resulting in failure of the apoptosis program and disruption of the epithelial-mesenchymal

10 interactions during embryonic development. Prenatal diagnosis is based on detection of renal

11 agenesis and laryngeal atresia together with a family history. Most of the fetuses with severe

12 anomalies are terminated or resulted in stillbirth. All patient or pregnancy with a diagnosis of FS

13 should be referred to expert centers. For the management, a collaborative approach of anesthetists,

14 ENT, maxillofacial surgeons, geneticists is necessary. In vivo and in vitro research models are

15 available to better understand the underlying etiology. 


\section{Introduction}

Fraser syndrome (FS), also known as cryptophthalmos-syndactyly syndrome (OMIM \#219000, http://omim.org/entry/219000), is an autosomal recessive malformation disorder. This Syndrome is characterized by cryptophthalmos, syndactyly, and abnormalities of the respiratory and urogenital tract $^{1-3}$. The diagnostic is established by clinical examination and is based on major criteria (cryptophthalmos; syndactyly; ambiguous genitalia, urinary and respiratory tract anomalies and an affected sibling) and minor criteria (congenital nose and ears malformations; skull ossification defects; Anorectal anomalies and umbilical hernia) $)^{3,4}$. While FS shows an interfamilial highly variable phenotype ranging from minor symptoms to lethal malformations like renal agenesis, there is a strong phenotypic similarity exists within a family³.

Numerous case reports of FS are published in literature since the first description of the syndromic association of cryptophtalmos-syndactily by George Fraser in $1962^{1}$. Most of them are clinical descriptions of fetuses from terminated pregnancy or stillbirth. The few reports of alive patients are usually pediatric cases.

Here, we provide a review of the epidemiology, the clinical presentation, the management, the physiopathology and the genetics of this syndrome especially for head and neck disorders. This review is supported by one new historical case of an adult patients with FS, never published before and managed by the maxillofacial Surgeon General Gustave Ginestet ${ }^{5,6}$ before the first publications of FS by George Fraser in 1962. 
37 FS is a rare disorder. A large epidemiological study in a European population showed a minimal estimated prevalence of 0.2 cases of FS per 100000 births and statistically more cases in west part of Europe compared to the rest of Europe $(p=0.0003)^{7}$. This prevalence represents a minimal estimate given that most of the fetuses with severe anomalies were terminated or resulted in stillbirth without syndrome diagnosis ${ }^{7}$. Regarding alive patients with FS, 25\% die within the first year of life, in most cases due to airways or urinary tract anomalies ${ }^{8}$. Only $n=3$ FS patient's aged more than 20 years

43 old are published in literature (Table1) $)^{2,9,10}$. At all, the prognosis for survival in individuals born with 44 this condition is in general poor ${ }^{11,12}$. 


\section{Clinical presentation and diagnosis}

\section{Diagnostic criteria}

In 1986 Thomas et al., were the first authors to report the criteria establishing the diagnosis of $\mathrm{FS}^{4}$. In 2007, after analyzing 59 cases of FS, van Haelst and the Fraser Syndrome Collaboration Group have confirmed the clinical utility of these criteria and included the airway tract and urogenital anomalies in the major criteria whereas mental retardation and clefts were removed from this list ${ }^{3}$ (table 2). At all, FS can be diagnosed, if two major and one minor criteria or one major and four minor criteria are present $^{3}$. All studies agreed that there was marked clinical variability and that none of the major criteria are mandatory for diagnosis. For some authors, within a family, the phenotype and the degree of severity of the disease are strongly concordant ${ }^{13}$.

\section{Clinical presentation}

The frequency of the most reported congenital anomalies in published Series of FS are summarized in table $3^{2-4,7,14,15}$. Unilateral or bilateral cryptophthalmos, syndactyly, unilateral renal agenesis and genital anomalies are the most frequent anomalies reported in literature. Apart cryptophtalmos other maxillofacial and oro-dental findings reported are facial asymmetry, upward slanting palpebral fissures, hypertelorism, tongue of hair extending from the anterior hairline to the forehead, the eyebrows and the upper-outer edge of the orbit, broad nose and/or nasal bridge (8-84\%), short neck, cleft lip and palate (11\%), high arched palate (12\%), malocclusion, dental crowding, fusion of primary teeth, dental hypoplasia, supragingival calculus, microdontia, retained deciduous teeth, hypodontia and short roots ${ }^{2,16-18}$ (Figure1a and 1b). Airway disorders (laryngeal compromise) are found in 21$83 \%$ of the cases of $\mathrm{FS}^{19}$. Subglottic stenosis and laryngeal webs or laryngotracheal atresia are the most frequent laryngotracheal disorder. Other rare ear-nose-throat anomalies are malformed and/or low set ears, meatal stenosis or dysplastic pinna and hypoplastic notched nares or choanal stenosis or atresia ${ }^{20}$. 
70 FS is classed among the hormonal disorders of sex development caused by hypogonadism ${ }^{21}$. 71 Reported genital anomalies are cryptorchidism and pseudo hermaphroditism for males and 72 masculinization of the external genitalia in females with clitoral hypertrophy, vaginal atresia, labial 73 fusion and gonadoblastoma ${ }^{22,23}$. Among anorectal disorders, anal atresia/stenosis are the most 74 common. Colonic atresia, diastema of the pubic symphysis, displacement of the umbilicus and 75 common mesentery have also been reported to illustrate abdominal anomalies associated with $\mathrm{FS}^{24}$. 76 Cardiac malformations, and musculoskeletal anomalies are uncommon?. A part syndactyly, 77 musculoskeletal abnormalities associated with FS include skull ossification defect, diastasis of the 78 pubic symphysis, bilateral hip dysplasia and genu valgum ${ }^{25}$. 


\section{Complementary exam}

80 The diagnosis of FS is based on the clinical exam. Complementary exams are realized to research

81 organ malformations. An abdominal echography is realized to investigate the urinary and genital

82 tracts. Skull ossification defects are evaluated with radiographies and/or CT-scan (computerized 83 tomography). 


\section{Physiopathology and genetics}

FS is an autosomal recessive malformation disorder ${ }^{26}$. The incidence of consanguinity in families with FS is estimated reaching $15 \%$ to $30 \%^{2,4,7,27}$. This syndrome seems to be related to a failure of the apoptosis program and to the formation of large blisters during embryonic development due to defects in epidermal adhesion (disruption of the epithelial-mesenchymal interactions) ${ }^{28-30}$. Indeed, in embryos, the Fraser complex $(\mathrm{FC})$ mediates epithelial-connective tissue interactions. This complex is composed of the Fras1/Frem family of Extra Cellular Matrix proteins ${ }^{29}$. These proteins have also been reported to mediate both the initiation of the mammalian kidney and glomerular maturation and integrity ${ }^{31,32}$. At all, Loss of expression of FC components leads to $\mathrm{FS}^{33}$.

Mutations in three different genes (FRAS1, FREM2, and GRIP1) have been identified causing $\mathrm{FS}^{34-39}$. Fraser syndrome-1 (FRASRS1) is caused by homozygous or compound heterozygous mutation in the FRAS1 gene (Fraser extracellular matrix complex subunit 1, OMIM * 607830) on chromosome 4q21. At all, 27 mutations of FRAS1 gene have been reported ${ }^{40,41}$. Most of them are truncating mutations. The mutational spectrum includes nucleotide substitutions, splicing defects, a large insertion, small deletions/insertions and a recently reported large deletion.

Fraser syndrome-2 (FRASRS2) is caused by mutation in the FREM2 gene (FRAS1 related extracellular matrix protein 2, OMIM *608945) on chromosome $13 q 13$.

Fraser syndrome-3 (FRASRS3) is caused by mutation in the GRIP1 gene (glutamate receptor interacting protein, OMIM * 604597) on chromosome 12q14. 
105 Renal anomalies, syndactyly and cryptophtalmos are present in more than $90 \%$ of cases of prenatal and postnatal fetal phenotype. However, they are rarely found on prenatal ultrasound because oligohydramnios, which is frequent, hampers the prenatal recognition of the cardinal FS diagnosis criteria $^{42,43}$. Thus, prenatal diagnosis of FS is often based on detection of some of the more easily detectable minor criteria, such as renal agenesis and laryngeal atresia, together with a family history. Aside from the presence of oligohydramnios, prenatal diagnosis can be sometimes challenging to establish especially if no previous child is affected ${ }^{44,45}$.

112 The prognosis of pregnancies with FS is poor and dependent on the predominant anomalies.

113 Termination of pregnancy may be recommended when diagnosis is made early, especially in the 114 setting of renal agenesis or laryngeal atresia ${ }^{46}$. In European countries, a large proportion of 115 pregnancies in this situation, up to $82 \%$ of cases, are medically interrupted. In all cases, prenatal diagnosis of FS should be guided by a genetic counselling ${ }^{47}$.

Molecular diagnosis

119 The antenatal and post-natal diagnosis of FS could be realized by targeted sequencing of a panel of 120 genes including FRAS1, FREM2 and GRIP1 genes ${ }^{48}$. 


\section{General management}

123

All patient or pregnancy with a diagnosis of FS should be referred to expert centers (https://www.orpha.net/consor/cgi-bin/Clinics Search.php?lng=EN) ${ }^{47}$. A Collaborative approach of experts' anesthetists, ENT, maxillofacial surgeons, geneticists is necessary.

\section{Anesthesia}

Although low incidence of complications was reported for general anesthesia in FS patients, all were related to the management of airways. Indeed, after reviewing $n=125$ general anesthesia for FS patients, Mathers et al., reported a high incidence (20\%) of difficult or impossible tracheal intubation due to glottic stenosis ${ }^{49}$.

\section{Airways}

Airway compromises represent a risk factor for death in infancy and early childhood, and appropriate management may be difficult due to the high incidence of recurrence, especially in the case of laryngeal webs ${ }^{19,50,51}$. Tracheostomy at birth could be necessary to keep the airway and preserve the patient's life $\mathrm{s}^{52}$. In other cases, laryngotracheal alterations should be researched to anticipate a difficult/impossible intubation ${ }^{53}$. Direct laryngoscopy can be realized to evaluate the severity of glottic web according to Cohen's classification ${ }^{54}$ and subglottic stenosis according to the Cotton-Myer scale $^{55}$. Endoscopic airway measurement combining optical endoscopic instruments with open source image processing can also be useful to accurately obtain airway dimensions ${ }^{56}$. All cases should be personalized managed. Although no guidelines can be given due to the small number of cases published in the literature, the cricotracheal resection seems to be an adequate alternative for surgical management in glottic-subglottic stenosis and severe laryngeal webs ${ }^{19}$.

\section{Ophthalmic malformations}


Cryptophthalmos, especially the eyelid defect, represents a challenge in surgical reconstruction and visual rehabilitation ${ }^{57}$. Saleh et al., published in 2009 a series of 13 eyes from 7 patients with FS with the aim to optimize visual potential for these patients ${ }^{58}$. The cryptophthalmos was complete in 3 eyes and abortive in 10 eyes. They concluded that the periocular surgical management of these type of complex cases should be planned using a systematic approach. Surgical steps should include dissection of corneal adhesions from keratinized cornea, mucous membrane graft, Mustarde eyelid switch flap with subsequent division, and further lower lid augmentation as required. Lessa et al., presented in 2011 present a two-stage surgical reconstruction procedure for correction of the upper eyelid and ocular bulb anomalies in cryptophthalmos (Mustardé's technique with fixation of the lower eyelid transposed flap to the levator muscle) $)^{59}$.

Lacrimal system dysgenesis and dacryocystoceles

Syndromic congenital nasolacrimal duct obstructions are not very common in FS patients ${ }^{60}$. Nasal endoscopic endonasal evaluation should be realized to research dacryocystoceles and realize drainage and marsupialization if necessary ${ }^{61}$.

\section{Dental care}

Self-dental cares can be difficult and/or impossible for FS patients especially when a mental retardation is present. Furthermore, cardiac abnormalities have been observed in 6 to $13 \%$ patients with $\mathrm{FS}^{2,7}$. Thus, $\mathrm{FS}$ patients have a predisposition to infective endocarditis ${ }^{17}$.

Moreover, it seems to be an association between the presence of dental plaque, periodontal disease, and chronic lung disease (especially pneumonia). Therefore, the establishment of oral health protocols with a goal of reducing the biofilm is essential. The dentists should realize the periodontal treatment with the clinical use of chlorhexidine and Povidone-iodine (PVP-I) ${ }^{62}$. The rehabilitation of occlusion with for example the placement of dental implants should be favorised ${ }^{18}$. 
$174 \quad$ In vivo/animal models

The bl ('blebbed') mouse model (http://omim.org/entry/219000)

In 1990, in a letter to the editors, Winter hypothesized that FS in human might be homologous to one of the mouse 'bleb' mutants phenotype ${ }^{63}$. Few years later in 1994, the genetic background of this 'blebbed' murine phenotype, has been more characterized by Darling and Gossler, especially the mutations in at least 5 loci, including $\mathrm{bl}^{64}$.

Then two major events confirmed that the bl mouse is a model for FS in humans. Firstly, the screening of the DNA from $\mathrm{bl} / \mathrm{bl}$ mice and the identification of a mutation in the Fras1 gene that resulting in premature protein termination ${ }^{35}$. Second, the demonstration that Fras1 deficiency (bl/bl homozygous embryos) results in cryptophthalmos, renal agenesis and blebbed phenotype in mice ${ }^{65}$.

Given these elements, the authors concluded the perturbation in the composition of extracellular space underlying epithelia by loss of Fras1 function characterize the blebbed phenotype in mice and FS in humans.

Regarding the implication of GRIP1 in the FS, Takamiya et al., showed in 2004 that Grip1 is required for normal cell-matrix interactions during early embryonic development and that there is a direct functional link between the multi-PDZ domain protein GRIP1 and Fras $1^{66}$. In 2006, Kiyozumi et al., report that Frem1 (FRAS1 related extracellular matrix protein 1, OMIM * 608944), Fras1, and Frem2 proteins are localized to the basement membrane, and that their basement membrane localization is simultaneously impaired in FS model mice (Grip1-mutant 'eye blebs' mice) ${ }^{67}$.

The Frem2 gene was reported as a cause of FS not linked to FRAS1 by Jadeja et al., in 2005 after performing linkage analysis in the 'myelencephalic blebs' (my) mice ${ }^{36}$. This model showed a phenotype similar to that of Fras1-mutant mice. 
At all, an article published in 2005 by Smyth and Scambler reviews the genetics of FS and of its homologs in the blebs mouse mutants ${ }^{68}$.

201

The fused pulmonary lobe 'fpl' mutant rat model

Fused pulmonary lobes (fpl) mutant rats exhibit similar phenotypes to $\mathrm{FS}^{69}$. Based on this the fpl gene harbors a nonsense mutation that introduced a stop codon in FS-associated gene Frem2. Thus, the Fpl mutant was defined as a first rats model of human $\mathrm{FS}^{70}$.

Zebrafish seems to be an ideal genetic model to understand the pathology and the genetic heterogeneity underlying $\mathrm{FS}^{33}$. In 2011, Talbot et al., have shown that zebrafish fras1 mutants exhibit defects in facial epithelia and facial skeleton which participated to the comprehension of the developmental basis of facial defects in $\mathrm{FS}^{71}$. The potential involvement of several other genes such as Hemicentin1 (HMCN1), Furin, and Fibrillin2 that interact in basement membrane anchorage has been proposed based on the study of zebrafish, suggesting further genetic heterogeneity for $\mathrm{FS}^{72}$. Zebrafish have also allowed the identification of novel component of the FC complex (the protein AMACO, an extra cellular matrix protein encoded by the VWA2 gene $)^{73}$.

$\underline{\text { In vitro model }}$

Four human cell lines derived from male FS patients are proposed by the Coriell Institute for Medical 


\section{Key historical events}

222 The first description of the cryptophtalmos-syndactily syndrome was reported in 2 pairs of siblings by

223 George Fraser in $1962^{1}$. Several key events have contributed to this description. In 79 AD, Pliny the

224 Elder (Gaius Plinius Secundus) reports in his Book VII of his "Naturalis Historia" the observation of a

225 couple having three children born with an eye covered by a skin membrane ${ }^{11,74}$. This is the first

226 report of "hidden eyes" with a family history. In 1872, Zehender and Manz introduced for the first

227 time the term cryptophthalmos ("hidden eye") to describe the case of a six-month old girl $\left.\right|^{75}$. In 1902 ,

228 Golowin reports the first case of an alive adults with cryptophthalmos and having an affected sister ${ }^{76}$.

229 In 1906 Asayama reported consanguine mice with cryptophthalmos which can be regarded as the

230 first cases of the blebbing mutants in mice ${ }^{77}$. The older literature on cryptophthalmos with

231 associated malformations was reviewed by Duke-Elder in $1963^{78}$. 


\section{New historical case of adult FS}

Presentation

We report the case of an adult untreated patient with FS from the personal collection of the Surgeon classically described in the syndrome but also some specific maxillofacial characteristics. The patient presented bilateral complete cryptophthalmos, bilateral coloboma of eyelid, bilateral and asymmetric cleft (on the right side the cleft was complete reaching the lip, the maxillary and palate while the cleft was limited to the lip on the left side), short philtrum. Nasal anomalies were a broad nose with midline groove towards the tip, hypoplastic nasal alae and widely set nostrils. The other maxillofacial disorders were facial asymmetry, musculo-skeletal abnormalities (hypoplasia of orbital bones), hypertelorism, a tongue of hair extending from the anterior hairline to the forehead, the eyebrows and the upper-outer edge of the orbit, a short neck, upward slanting palpebral fissures. The dental exam found dental hypoplasia and microdontia (Fig1a, 1b).

Maxillofacial management

This patient was surgically managed by the maxillofacial surgeon General Gustave Ginestet. Thus, he was operated several times (multi-step strategy) for its maxillofacial disorders before the first description of cryptophtalmos-Syndactily syndrome by George Fraser in $1962^{1}$ (Fig1c, 1d and Fig2). Firstly, the patient was operated to repair the bilateral cleft with primary cheiloplasty and rhinoplasty (Fig 1c, 1d). Then, several other rhinoplasties and cheiloplasties were realized (Fig2). Briefly, bilateral local foreheads, orbital flaps were prepared and progressively modified until allowing reconstruction of the nasal base with the two nostrils, the tip and the supra tip. The final result is very interesting 


\section{Conclusion}

258 Fraser syndrome (FS) was first described in 2 pairs of siblings by George Fraser in 1962. To date, more 259 than 250 patients have been described in the literature. The clinical variability associated with FS 260 supports the genetic heterogeneity of the syndrome. To our knowledge, there have been only $n=3$ 261 previously reported cases of a patient fulfilling the diagnostic criteria for FS and surviving over the 262 age of 20 years. Numerous clinical trials and research models are available to better characterize this 263 syndrome in clinical, pathophysiological and genetic terms. 
265 The authors thank the French association of face surgeons "AFCF: Association Française des 266 Chirurgiens de la Face" for giving opportunity to study the Surgeon General Gustave Ginestet 267 archives.

268 All authors have viewed and agreed to the submission. 


\section{Reference}

1. Fraser GR. Our genetical 'load'. A review of some aspects of genetical variation. Annals of Human Genetics 1962;25(4):387-415. Doi: 10.1111/j.1469-1809.1962.tb01774.x.

2. Slavotinek AM., Tifft CJ. Fraser syndrome and cryptophthalmos: review of the diagnostic criteria and evidence for phenotypic modules in complex malformation syndromes. $J$ Med Genet 2002;39(9):623-33.

3. van Haelst MM., Scambler PJ., Fraser Syndrome Collaboration Group, Hennekam RCM. Fraser syndrome: a clinical study of 59 cases and evaluation of diagnostic criteria. Am J Med Genet A 2007;143A(24):3194-203. Doi: 10.1002/ajmg.a.31951.

4. Thomas IT., Frias JL., Felix V., Sanchez de Leon L., Hernandez RA., Jones MC. Isolated and syndromic cryptophthalmos. Am J Med Genet 1986;25(1):85-98. Doi: 10.1002/ajmg.1320250111.

5. Brue E., Salf E. [Gustave Ginestet (1897-1966), doctor general. Life and work of a pioneer of cosmetic and reconstructive maxillofacial surgery]. Hist Sci Med 1995;29(4):307-15.

6. [Surgeon General Gustave Ginestet 1897-1966]. Rev Fr Odontostomatol 1966;13(5):704-9.

7. Barisic I., Odak L., Loane M., Garne E., Wellesley D., Calzolari E., et al. Fraser Syndrome: Epidemiological Study in a European Population. American Journal of Medical Genetics Part A 2013;161(5):1012-8. Doi: 10.1002/ajmg.a.35839.

8. Boyd PA., Keeling JW., Lindenbaum RH. Fraser syndrome (cryptophthalmos-syndactyly syndrome): a review of eleven cases with postmortem findings. Am J Med Genet 1988;31(1):159-68. Doi: 10.1002/ajmg.1320310119.

9. Impallomeni M., Subramanian D., Mahmood N., Illes J., Joseph I. Fraser syndrome in a 96year-old female. Age Ageing 2006;35(6):642-3. Doi: 10.1093/ageing/afl109.

10. Zhang HC. Cryptophthalmos: a report on three sibling cases. Br J Ophthalmol 1986;70(1):724. 
11. Fraser GR. Fraser Syndrome: Two millennia of cryptophthalmos from Pliny the Elder to FRAS, FREM and GRIP: A historical perspective. Open Journal of Genetics 2013;03:1. Doi: 10.4236/ojgen.2013.32A3001.

12. Comstock JM., Putnam AR., Opitz JM., Pysher TJ., Szakacs J. Prenatal Death in Fraser Syndrome. Fetal and Pediatric Pathology 2005;24(4-5):223-38. Doi: 10.1080/15227950500405353.

13. Abdalla EM., Zayed LH., Issa NM., Amin AK. Fraser syndrome: Phenotypic variability and unusual findings in four Egyptian families. Egyptian Journal of Medical Human Genetics 2016;17(2):233-8. Doi: 10.1016/j.ejmhg.2015.10.004.

14. Gattuso J., Patton MA., Baraitser M. The clinical spectrum of the Fraser syndrome: report of three new cases and review. J Med Genet 1987;24(9):549-55.

15. Eskander BS., Shehata BM. Fraser syndrome: a new case report with review of the literature. Fetal Pediatr Pathol 2008;27(2):99-104. Doi: 10.1080/15513810802077628.

16. Keene EJ., Day PF. Case report: hypodontia and short roots in a child with Fraser syndrome. Eur Arch Paediatr Dent 2011;12(4):216-8.

17. Hassona Y., Kharoub H., Scully C. Oral healthcare in Fraser syndrome. Special Care in Dentistry 2017;37(5):263-6. Doi: 10.1111/scd.12247.

18. Gallottini M., Llanos AH., Romito GA., Romano MM., de Oliveira FB., de Rezende NPM. Oral manifestations and rehabilitation in Fraser syndrome: A case report. Spec Care Dentist 2018;38(4):249-54. Doi: 10.1111/scd.12297.

19. Alvaréz-Neri H., Morán VF., De La Torre C., Villamor P., Penchyna Grub J. Airway features in Fraser syndrome: Case report and literature review. International Journal of Pediatric Otorhinolaryngology Extra 2017;18:16-8. Doi: 10.1016/j.pedex.2017.09.004.

20. Ford GR., Irving RM., Jones NS., Bailey CM. ENT manifestations of Fraser syndrome. The Journal of Laryngology \& Otology 1992;106(1):1-4. Doi: 10.1017/S0022215100118444. 
21. Hutson JM., Grover SR., O'Connell M., Pennell SD. Malformation syndromes associated with disorders of sex development. Nature Reviews Endocrinology 2014;10(8):476-87. Doi:

10.1038/nrendo.2014.83.

\section{Frazer GR. XX CHROMOSOMES AND RENAL AGENESIS. The Lancet}

1966;287(7452):1427. Doi: 10.1016/S0140-6736(66)90344-8.

23. Greenberg F., Keenan B., De Yanis V., Finegold M. Gonadal dysgenesis and gonadoblastoma in situ in a female with Fraser (cryptophthalmos) syndrome. The Journal of Pediatrics 1986;108(6):952-4. Doi: 10.1016/S0022-3476(86)80939-8.

24. Narang M., Kumar M., Shah D. Fraser-cryptophthalmos syndrome with colonic atresia. Indian J Pediatr 2008;75(2):189. Doi: 10.1007/s12098-008-0030-9.

25. Price CT. The Presence of Bilateral Hip Dysplasia and Genu Valgum in Fraser Syndrome. ORTHOPEDICS 2008;31(1). Doi: 10.3928/01477447-20080101-17.

26. Francannet C., Lefrançois P., Dechelotte P., Robert E., Malpuech G., Robert JM. Fraser syndrome with renal agenesis in two consanguineous Turkish families. American Journal of Medical Genetics 1990;36(4):477-9. Doi: 10.1002/ajmg.1320360421.

27. Martínez-Frías ML., Bermejo Sánchez E., Félix V., Calvo Celada R., Ayala Garcés A., Hernández Ramón F. [Fraser syndrome: frequency in our environment and clinical-epidemiological aspects of a consecutive series of cases]. An Esp Pediatr 1998;48(6):634-8.

28. Short K., Wiradjaja F., Smyth I. Let's stick together: the role of the Fras1 and Frem proteins in epidermal adhesion. IUBMB Life 2007;59(7):427-35. Doi: 10.1080/15216540701510581.

29. Pavlakis E., Chiotaki R., Chalepakis G. The role of Fras1/Frem proteins in the structure and function of basement membrane. Int J Biochem Cell Biol 2011;43(4):487-95. Doi:

10.1016/j.biocel.2010.12.016.

30. Hines EA., Verheyden JM., Lashua AJ., Larson SC., Branchfield K., Domyan ET., et al. 
Syndactyly in a novel Fras1rdf mutant results from interruption of signals for interdigital apoptosis. Developmental Dynamics 2016;245(4):497-507. Doi: 10.1002/dvdy.24389.

31. Pitera JE., Scambler PJ., Woolf AS. Fras1, a basement membrane-associated protein mutated in Fraser syndrome, mediates both the initiation of the mammalian kidney and the integrity of renal glomeruli. Hum Mol Genet 2008;17(24):3953-64. Doi: 10.1093/hmg/ddn297.

32. Pitera JE., Turmaine M., Woolf AS., Scambler PJ. Generation of mice with a conditional null fraser syndrome 1 (Fras1) allele. Genesis 2012;50(12):892-8. Doi: 10.1002/dvg.22045.

33. Hiroyasu S., Jones JCR. A New Component of the Fraser Complex. J Invest Dermatol 2014;134(5):1192-3. Doi: 10.1038/jid.2013.514.

34. van Haelst MM., Maiburg M., Baujat G., Jadeja S., Monti E., Bland E., et al. Molecular study of 33 families with Fraser syndrome new data and mutation review. Am J Med Genet A 2008;146A(17):2252-7. Doi: 10.1002/ajmg.a.32440.

35. McGregor L., Makela V., Darling SM., Vrontou S., Chalepakis G., Roberts C., et al. Fraser syndrome and mouse blebbed phenotype caused by mutations in FRAS1/Fras1 encoding a putative extracellular matrix protein. Nat Genet 2003;34(2):203-8. Doi: 10.1038/ng1142.

36. Jadeja S., Smyth I., Pitera JE., Taylor MS., van Haelst M., Bentley E., et al. Identification of a new gene mutated in Fraser syndrome and mouse myelencephalic blebs. Nat Genet 2005;37(5):520-5. Doi: $10.1038 / n g 1549$.

37. Shafeghati Y., Kniepert A., Vakili G., Zenker M. Fraser syndrome due to homozygosity for a splice site mutation of FREM2. Am J Med Genet A 2008;146A(4):529-31. Doi: 10.1002/ajmg.a.32091.

38. Vogel MJ., van Zon P., Brueton L., Gijzen M., van Tuil MC., Cox P., et al. Mutations in GRIP1 cause Fraser syndrome. J Med Genet 2012;49(5):303-6. Doi: 10.1136/jmedgenet-2011100590. 
39. Schanze D., Kayserili H., Satkın BN., Altunoglu U., Zenker M. Fraser syndrome due to mutations in GRIP1 - Clinical phenotype in two families and expansion of the mutation spectrum. American Journal of Medical Genetics Part A 2014;164(3):837-40. Doi: 10.1002/ajmg.a.36343.

40. Hoefele J., Wilhelm C., Schiesser M., Mack R., Heinrich U., Weber LT., et al. Expanding the mutation spectrum for Fraser syndrome: identification of a novel heterozygous deletion in FRAS1. Gene 2013;520(2):194-7. Doi: 10.1016/j.gene.2013.02.031.

41. Nayak SS., Salian S., Shukla A., Mathew M., Girisha KM. Variable presentation of Fraser syndrome in two fetuses and a novel mutation in FRAS1. Congenital Anomalies 2017;57(3):83-5. Doi: $10.1111 /$ cga. 12188.

42. Tessier A., Sarreau M., Pelluard F., André G., Blesson S., Bucourt M., et al. Fraser syndrome: features suggestive of prenatal diagnosis in a review of 38 cases. Prenat Diagn 2016;36(13):1270-5. Doi: $10.1002 / p d .4971$.

43. De Bernardo G., Giordano M., Di Toro A., Sordino D., De Brasi D. Prenatal diagnosis of Fraser syndrome: a matter of life or death? Ital J Pediatr 2015;41:86. Doi: 10.1186/s13052-015-01956.

44. Rousseau T., Laurent N., Thauvin-Robinet C., Lionnais S., Durand C., Faivre L., et al. Prenatal diagnosis and intrafamilial clinical heterogeneity of Fraser syndrome. Prenatal Diagnosis 2002;22(8):692-6. Doi: 10.1002/pd.381.

45. Berg C., Geipel A., Germer U., Pertersen-Hansen A., Koch-DÖrfler M., Gembruch U. Prenatal detection of Fraser syndrome without cryptophthalmos: case report and review of the literature. Ultrasound in Obstetrics \& Gynecology 2001;18(1):76-80. Doi: 10.1046/j.14690705.2001.00374.x.

46. Tuuli MG., Odibo AO. 128 - Fraser Syndrome. In: Copel JA, D’Alton ME, Feltovich H, Gratacós E, Krakow D, Odibo AO et al., editors. Obstetric Imaging: Fetal Diagnosis and Care (Second Edition). Elsevier; 2018. p. 547-549.e1. 
47. Chen H. Fraser Syndrome. In: Chen H, editor. Atlas of Genetic Diagnosis and Counseling. New York, NY: Springer New York; 2017. p. 1143-51.

48. Kornacki J., Sowińska-Seidler A., Socha M., Ropacka M., Jamsheer A. Prenatal diagnosis of Fraser syndrome using routine ultrasound examination, confirmed by exome sequencing: Report of a novel homozygous missense FRAS1 mutation. Congenital Anomalies 2017;57(1):37-8. Doi:

10.1111/cga.12177.

49. Mathers JD., Breen TM., Smith JH. Delivery of anesthesia and complications for children with Fraser syndrome: a review of 125 anesthetics. Paediatr Anaesth 2014;24(12):1288-94. Doi: 10.1111/pan.12522.

50. Somme S., Crombleholme TM. Prenatal Assessment and Perinatal Management of Suspected Airway Compromise in the Fetus and Neonate. In: Lioy J, and Sobol SE, editors. Disorders of the Neonatal Airway: Fundamentals for Practice. New York, NY: Springer New York; 2015. p. 167-80.

51. Izadi F., Ahmadi A., Zobairy H., Bakhti S., Hirbod H., Safdarian M. Fraser syndrome with laryngeal webs: Report of two cases and a review of the literature. Int J Pediatr Otorhinolaryngol 2015;79(11):1959-62. Doi: 10.1016/j.ijporl.2015.08.043.

52. Crowe S., Westbrook A., Bourke M., Lyons B., Russell J. Impossible laryngeal intubation in an infant with Fraser syndrome. Paediatr Anaesth 2004;14(3):276-8.

53. Okumus N., Onal EE., Turkyilmaz C., Biri A., Gönül II., Unal S., et al. Resuscitation failure due to Fraser syndrome in a newborn undiagnosed in the prenatal period. Resuscitation 2005;65(2):221-3. Doi: 10.1016/j.resuscitation.2004.11.015.

54. Cohen SR. Congenital glottic webs in children. A retrospective review of 51 patients. Ann Otol Rhinol Laryngol Suppl 1985;121:2-16.

55. Myer CM., O’Connor DM., Cotton RT. Proposed grading system for subglottic stenosis based on endotracheal tube sizes. Ann Otol Rhinol Laryngol 1994;103(4 Pt 1):319-23. Doi:

10.1177/000348949410300410. 
56. Francom CR., Best CA., Eaton RG., Pepper V., Onwuka AJ., Breuer CK., et al. Clinical validation and reproducibility of endoscopic airway measurement in pediatric aerodigestive evaluation. Int J Pediatr Otorhinolaryngol 2019;116:65-9. Doi: 10.1016/j.ijporl.2018.10.004.

57. Sullivan TJ., Clarke MP., Rootman DS., Pashby RC. Eyelid and fornix reconstruction in bilateral abortive cryptophthalmos (Fraser syndrome). Aust N Z J Ophthalmol 1992;20(1):51-6.

58. Saleh GM., Hussain B., Verity DH., Collin JRO. A surgical strategy for the correction of Fraser syndrome cryptophthalmos. Ophthalmology 2009;116(9):1707-1712.e1. Doi:

10.1016/j.ophtha.2009.05.018.

59. Lessa S., Nanci M., Sebastiá R., Flores E. Two-stage reconstruction for eyelid deformities in partial cryptophthalmos. Ophthalmic Plast Reconstr Surg 2011;27(4):282-6. Doi:

10.1097/IOP.0b013e318201d627.

60. Ali M., Gupta S., Patel A., Naik M. Lacrimal Drainage Anomalies in Fraser Syndrome. Ophthalmic Plastic and Reconstructive Surgery 2018;34(1):92-3. Doi:

10.1097/IOP.0000000000001026.

61. Falls ME., Rabinowitz MP., Carrasco JR., Rabinowitz MR. Endoscopic Management of Lacrimal System Dysgenesis and Dacryocystoceles in Fraser Syndrome: A Case Report and Literature Review. Allergy Rhinol (Providence) 2018;9. Doi: 10.1177/2152656718804905.

62. de Oliveira TL., de Sant'Anna GR. Fraser Syndrome-Oral Manifestations and a Dental Care Protocol. Case Reports in Dentistry. Doi: 10.1155/2014/486108.

63. Winter RM. Fraser syndrome and mouse "bleb" mutants. Clin Genet 1990;37(6):494-5.

64. Darling S., Gossler A. A mouse model for Fraser syndrome? Clin Dysmorphol 1994;3(2):915.

65. Vrontou S., Petrou P., Meyer BI., Galanopoulos VK., Imai K., Yanagi M., et al. Fras1 deficiency results in cryptophthalmos, renal agenesis and blebbed phenotype in mice. Nat Genet 
2003;34(2):209-14. Doi: 10.1038/ng1168.

66. Takamiya K., Kostourou V., Adams S., Jadeja S., Chalepakis G., Scambler PJ., et al. A direct functional link between the multi-PDZ domain protein GRIP1 and the Fraser syndrome protein Fras1. Nat Genet 2004;36(2):172-7. Doi: 10.1038/ng1292.

67. Kiyozumi D., Sugimoto N., Sekiguchi K. Breakdown of the reciprocal stabilization of QBRICK/Frem1, Fras1, and Frem2 at the basement membrane provokes Fraser syndrome-like defects. Proc Natl Acad Sci USA 2006;103(32):11981-6. Doi: 10.1073/pnas.0601011103.

68. Smyth I., Scambler P. The genetics of Fraser syndrome and the blebs mouse mutants. Hum Mol Genet 2005;14(suppl_2):R269-74. Doi: 10.1093/hmg/ddi262.

69. Aoyama H., Teramoto S., Shirasu Y. Heritable pulmonary lobation anomaly in the rat. Teratology 1988;37(2):159-66. Doi: 10.1002/tera.1420370209.

70. Kiyozumi D., Nakano I., Takahashi KL., Hojo H., Aoyama H., Sekiguchi K. Fused pulmonary lobes is a rat model of human Fraser syndrome. Biochem Biophys Res Commun 2011;411(2):440-4. Doi: 10.1016/j.bbrc.2011.06.174.

71. Talbot JC., Walker MB., Carney TJ., Huycke TR., Yan Y-L., BreMiller RA., et al. fras1 shapes endodermal pouch 1 and stabilizes zebrafish pharyngeal skeletal development. Development 2012;139(15):2804-13. Doi: 10.1242/dev.074906.

72. Carney TJ., Feitosa NM., Sonntag C., Slanchev K., Kluger J., Kiyozumi D., et al. Genetic analysis of fin development in zebrafish identifies furin and hemicentin1 as potential novel fraser syndrome disease genes. PLoS Genet 2010;6(4):e1000907. Doi: 10.1371/journal.pgen.1000907.

73. Richardson RJ., Gebauer JM., Zhang J-L., Kobbe B., Keene DR., Karlsen KR., et al. AMACO is a novel component of the basement membrane associated Fraser complex. J Invest Dermatol 2014;134(5):1313-22. Doi: 10.1038/jid.2013.492.

74. Gaius Plinius Secundus (Pliny the Elder). Naturalis Historia (77-79). Available at 
https://www.oddsalon.com/naturalis-historia/. Accessed April 5, 2019.

75. zehender w., Manz. Eine missgeburt mit hautüberwachsenen augen oder kryptophthalmus. Klinische Monatsblätter Für Augenheilkunde 1872;4:225-34.

76. Golowin S. III. Beiträge zur Anatomie und Pathogenese des Kryptophthalmus congenitus. OPH 1902;8(Suppl. 1):175-212. Doi: 10.1159/000289955.

77. ASAYAMA. Vererbung von kryptophthalmus. Klinische Monatsblätter Für Augenheilkunde 1906;4:346.

78. Duke-Elder S. Normal and Abnormal Development. Part 2. Congenital Deformities. System of Ophthalmology, vol. 3. C. V. Mosby. St. Louis; 1963. p. 829-34. 


\section{Figure and table legends}

Figure 1. Historical case of an adult patient surgically managed by the maxillofacial surgeon General Gustave Ginestet before the first publications of FS by George Fraser in 1962. 1a and 1b: The patient presented some maxillofacial malformations classically described in the FS: bilateral complete cryptophthalmos, bilateral coloboma of eyelid, the eyebrows and the upper-outer edge of the orbit, upward slanting palpebral fissures, a tongue of hair extending from the anterior hairline to the forehead, facial asymmetry, hypertelorism, bilateral and asymmetric cleft (on the right side the cleft was complete reaching the lip, the maxillary and palate while the cleft was limited to the lip on the left side), short philtrum, a short neck. Nasal anomalies were a broad nose with midline groove towards the tip, hypoplastic nasal alae and widely set nostrils. Dental anomalies were dental hypoplasia and microdontia. All these elements are particularly suggestive of the FS; $1 \mathrm{c}$ and $1 \mathrm{~d}$ : bilateral cleft repair with primary cheiloplasty and rhinoplasty. (FS: Fraser Syndrome)

Figure 2. Multi step surgical strategy realized by the maxillofacial surgeon General Gustave Ginestet to manage an historical case of an adult patient with FS. 2a and 2b: Preparation of bilateral local foreheads, orbital flaps to reconstruct the nasal base with the two nostrils, the tip and the supra tip. $2 \mathrm{c}$ and $2 \mathrm{~d}$ : final results of the surgical management. The aesthetic result is very interesting. (FS: Fraser Syndrome)"

Table 1. Adult cases (age 20 years old) of Fraser Syndrome reported in literature. (NA: non-available)

Table 2. Diagnostic criteria for Fraser syndrome published by Van Haelst et al.,2007.

Table 3. Frequency of the most reported congenital anomalies for published series of patient with Fraser syndrome.

Table 4. Human cell lines derived from male FS patients proposed by the Coriell Institute for Medical Research (New Jersey, United Stated, https://www.coriell.org/OmimNum:219000) (LCL: Lymphoblastoid Cell lines; DNA: deoxyribonucleotidic acid; YR: years; FW: fetal weeks). 